\title{
FAKTOR-FAKTOR YANG BERPENGARUH TERHADAP PRESTASI BELAJAR TEORI KEJURUAN SISWA SMK
}

\author{
Narwoto \\ SMK Muhammadiyah 3 Yogyakarta \\ e-mail: den_woto@yahoo.com \\ Soeharto \\ Universitas Negeri Yogyakarta \\ Abstrak
}

\begin{abstract}
Penelitian ini bertujuan untuk mengetahui pengaruh kinerja mengajar guru, pemanfaatan fasilitas belajar dan motivasi berprestasi baik secara parsial maupun simultan terhadap prestasi belajar teori kejuruan siswa SMK Kompetensi Keahlian Teknik Instalasi Tenaga Listrik di Kota Yogyakarta. Populasi dalam penelitian ini adalah siswa kelas XII kompetensi keahlian teknik instalasi tenaga listrik di SMK se-Kota Yogyakarta. Sampel sejumlah 170 siswa ditentukan menggunakan proportional random sampling technique dengan rumus Slovin. Intrumen yang digunakan adalah angket tertutup dan tes tentang teori kejuruan. Analisis data menggunakan teknik regresi linier sederhana dan regresi linier ganda dengan taraf signifikansi 5\%. Hasil penelitian adalah sebagai berikut. (1) Terdapat pengaruh yang signifikan antara kinerja mengajar guru terhadap prestasi belajar teori kejuruan dengan besarnya pengaruh adalah 32,8 \%. (2) Terdapat pengaruh yang signifikan antara pemanfaatan fasilitas belajar terhadap prestasi belajar teori kejuruan dengan besarnya pengaruh adalah $9 \%$. (3) Terdapat pengaruh yang signifikan antara motivasi berprestasi siswa terhadap prestasi belajar teori kejuruan dengan besarnya pengaruh adalah 14,1 \%. (4) Terdapat pengaruh yang signifikan antara kinerja mengajar guru, pemanfaatan fasilitas belajar dan motivasi berprestasi siswa secara bersama-sama terhadap prestasi belajar teori kejuruan dengan besarnya pengaruh secara simultan adalah 34,3\%, sedangkan 63,7\% dipengaruhi oleh faktor yang lain.
\end{abstract}

Kata kunci: kinerja mengajar guru, pemanfaatan fasilitas belajar, motivasi berprestasi

\section{THE FACTORS THAT EFFECT FOR STUDENTS ACHIEVEMENT OF VOCATIONAL THEORY IN VOCATIONAL HIGH SCHOOL (SMK)}

\begin{abstract}
The purpose of this study was to examine the effect of teachers' teaching performance, utilization of the learning facilities, and achievement motivation either individually or simultaneously on the achievement of vocational theory of electrical power engineering of the students of vocational high schools in Yogyakarta City. The population in this study was students of class XII in electrical power engineering skill competency at vocational high schools in Yogyakarta City. A sample of 170 students was established using the proportional random sampling technique with Slovin formula. The instruments used were a closed questionnaire and test of the vocational theory. The data analysis used simple linear regression and multiple linear regression analyses with the significance level of 5\%. The results are as follows. (1) There is a significant effect of teachers' teaching performance on their achievement in vocational theory with the magnitude of effect of $32.8 \%$. (2) There is a significant effect of the utilization of learning facilities on the students' achievement in vocational theory with the magnitude of effect of $9 \%$. (3) There is a significant effect of students' achievement motivation on their achievement in vocational theory, with the magnitude of effect of $14.1 \%$. (4) There is a significant effect of teachers' teaching performance, their utilization of learning facilities, and their achievement motivation on their achievement in vocational theory with the simultaneous magnitude of effect of $34.3 \%$, while $63.7 \%$ is affected by other factors.
\end{abstract}

Keywords: teachers' teaching performance, utilization of learning facilities, achievement motivation 


\section{PENDAHULUAN}

Kehidupan pada era globalisasi menuntut kualitas sumber daya manusia yang handal agar dapat bertahan dalam kehidupan yang penuh dengan persaingan. Usaha yang dapat dilakukan untuk mewujudkan kualitas sumber daya manusia yang handal tersebut adalah melalui dunia pendidikan. Hal tersebut dikarenakan dunia pendidikan mempunyai peranan yang sangat strategis untuk mencetak sumber daya manusia yang siap menghadapi persaingan bebas.

Salah satu sistem pendidikan yang mampu mencetak sumber daya manusia yang handal dan siap bersaing di dunia kerja adalah pendidikan kejuruan. Menurut Undang-Undang Republik Indonesia Nomor 20 Tahun 2003 tentang Sistem Pendidikan Nasional, pendidikan kejuruan merupakan pendidikan yang mempersiapkan peserta didik untuk dapat bekerja dalam bidang tertentu. Senada dengan hal tersebut, Finch dan Crunkilton (1999: 10) menyebutkan bahwa tujuan pendidikan kejuruan ada dua macam yaitu pendidikan untuk hidup (education for life) dan pendidikan untuk mendapatkan penghasilan dalam hidup (education for earning a living). Kedua tujuan tersebut akan terlaksana jika pendidikan kejuruan diarahkan pada pencapaian kompetensi seseorang. Realisasi pendidikan kejuruan untuk mewujudkan tujuan tersebut diselenggarakan oleh pemerintah melalui Sekolah Menengah Kejuruan (SMK).

Sekolah Menengah Kejuruan (SMK) merupakan salah satu bentuk satuan pendidikan formal yang menyelenggarakan pendidikan kejuruan pada jenjang pendidikan menengah. Menurut Wardiman (1998: 36) tujuan SMK adalah mempersiapkan peserta didik sebagai calon tenaga kerja dan mengembangkan eksistensi peserta didik, untuk kepentingan peserta didik, masyarakat, bangsa dan negara. Tujuan yang mulia tersebut mengharuskan SMK untuk bertanggung jawab dalam pembenahan, peningkatan keahlian dan keterampilan peserta didik sehingga mampu menghasilkan tenaga kerja yang berkualitas dan terpercaya untuk memasuki dunia kerja. Oleh karena itu SMK harus siap mengemban misi pembangunan untuk menghasilkan sumber daya manusia yang berkualitas

Indikator pencapaian kualitas pendidikan di SMK terlihat dari kompetensi yang dikuasai oleh para peserta didik. Menurut Finch \& Crunkilton (1999: 259) kompetensi didefinisikan sebagai penguasaan terhadap suatu tugas, keterampilan, sikap, nilai dan apresiasi yang diperlukan untuk menunjang keberhasilan dalam kehidupan. Tingkat pencapaian kompetensi yang dikuasai peserta didik tersebut dapat dilihat dan diukur melalui Uji Kompetensi Keahlian (UKK).

UKK yang dilaksanakan di SMK dituangkan dalam bentuk soal teori kejuruan dan praktik kejuruan yang sesuai dengan kriteria kinerja (performance criteria). UKK pada SMK tersebut juga merupakan bagian dari Ujian Nasional yang menjadi indikator ketercapaian standar kompetensi lulusan, sedangkan bagi stakeholder akan dijadikan sebagai informasi atas kompetensi yang dimiliki si calon tenaga kerja (Kemendiknas, 2012: 1).

Pada pelaksanaan Uji Kompetensi Keahlian, penyelenggara Tingkat Pusat menentukan kelulusan ujian kompetensi keahlian sesuai persyaratan kelulusan ujian Kompetensi Keahlian sebagaimana diatur pada Peraturan Badan Standar Nasional Pendidikan (BSNP) Kemendiknas. Standar yang ditetapkan BNSP adalah nilai kompetensi keahlian kejuruan adalah gabungan antara nilai ujian praktik keahlian kejuruan dan nilai ujian teori kejuruan dengan pembobotan $70 \%$ untuk nilai ujian praktik keahlian kejuruan dan 30\% untuk nilai ujian teori keahlian kejuruan. Ujian praktik kejuruan dinyatakan kompeten atau lulus jika nilainya minimal 7,00 sedangkan kriteria kelulusan kompetensi keahlian kejuruan adalah minimum 6,0 (Kemendiknas, 2011: 25). Oleh karena itu, baik nilai ujian praktik kejuruan maupun nilai ujian teori kejuruan merupakan salah satu indikator pencapaian kompetensi siswa.

Uji Kompetensi Keahlian Teknik Instalasi Tenaga Listrik di SMK berfungsi sebagai indikator ketercapaian standar kompetensi lulusan, sedangkan bagi stakeholder akan dijadikan sebagai informasi atas kompetensi yang dimiliki si calon tenaga kerja. Siswa yang kompeten akan ditunjukkan dengan prestasi belajar uji kompetensi yang diikutinya baik teori kejuruan maupun praktik kejuruan.

Menurut BNSP, uji teori kejuruan bertujuan untuk mengukur pengetahuan dan pemahaman peserta didik terhadap landasan ke- 
ilmuan di samping untuk menguji analisis, daya nalar dan penyelesaian masalah, sedangkan Praktik Kejuruan mengukur kemampuan peserta uji dalam mengerjakan sebuah penugasan atau membuat suatu produk sesuai tuntutan standar kompetensi. Oleh karena itu, prestasi belajar praktik kejuruan maupun teori kejuruan harus mendapat perhatian yang serius dari sekolah sebagai indikator kompetensi siswa.

Pencapaian prestasi belajar siswa SMK khususnya Kompetensi Keahlian Teknik Instalasi Tenaga Listrik dipengaruhi oleh berbagai faktor. Studi yang dilakukan Heynemen \& Loxley pada tahun 1983 di 29 negara menemukan bahwa diantara berbagai masukan (input) yang menentukan pendidikan (yang ditunjukkan oleh prestasi belajar) sepertiganya ditentukan oleh guru. Peranan guru semakin penting ditengah keterbatasan sarana dan prasarana sebagaimana yang dialami oleh negara-negara yang sedang berkembang. Lengkapnya hasil studi itu adalah: di 16 negara sedang berkembang, guru memberi kontribusi terhadap prestasi belajar sebesar $34 \%$, sedangkan manajemen $22 \%$, waktu belajar 18\% dan sarana fisik 26\%. Studi di 13 negara industri menunjukkan bahwa kontribusi guru adalah $36 \%$, manajemen $23 \%$, waktu belajar 22\% dan sarana fisik 19\% (Dedi Supriadi, 1999:178). Oleh karena itu faktor guru, manajemen, waktu belajar dan sarana fisik mempunyai pengaruh terhadap prestasi belajar siswa

Berdasarkan uraian di atas, maka dapat disimpulkan bahwa uji teori kejuruan bertujuan untuk mengukur pengetahuan dan pemahaman peserta didik terhadap landasan keilmuan di samping untuk menguji analisis, daya nalar dan penyelesaian masalah. Uji teori kejuruan juga mempunyai kontribusi terhadap nilai kompetensi keahlian kejuruan sebesar 30 $\%$. Oleh karena itu perlu dilakukan penelitian terhadap faktor-faktor yang dapat mempengaruhi prestasi belajar teori kejuruan di SMK.

Faktor-faktor yang diduga mempunyai pengaruh yang kuat terhadap prestasi belajar teori kejuruan antara lain kinerja mengajar guru, pemanfaatan fasilitas belajar dan motivasi berprestasi siswa. Hal tersebut dikarenakan guru mempunyai peran yang strategis untuk meningkatkan prestasi belajar siswa melalui proses pembelajaran yang dilakukan didukung dengan pemanfaatan fasilitas belajar yang optimal dan motivasi dari siswa untuk berprestasi.

\section{METODE PENELITIAN}

Jenis penelitian ini adalah Ex post Facto dengan pendekatan kuantitatif. Menurut Sugiyono (2011: 7), metode penelitian Ex post Facto digunakan untuk meneliti peristiwa yang telah terjadi dan kemudian merunut ke belakang untuk mengetahui faktor-faktor yang dapat menyebabkan timbulnya kejadian tersebut. Pendekatan kuantitatif pada penelitian ini digunakan untuk mendeskripsikan hasil penelitian yang berbentuk matematik Terdapat tiga variabel pada penelitian yaitu dua variabel terikat dan satu variabel bebas. Variabel bebasnya adalah kinerja mengajar guru $\left(\mathrm{X}_{1}\right)$, pemanfaatan fasilitas belajar $\left(\mathrm{X}_{2}\right)$, dan motivasi berprestasi siswa $\left(\mathrm{X}_{3}\right)$ sedangkan variabel terikatnya adalah prestasi belajar teori kejuruan (Y). Desain penelitian dapat dilihat pada gambar 1 di bawah ini.

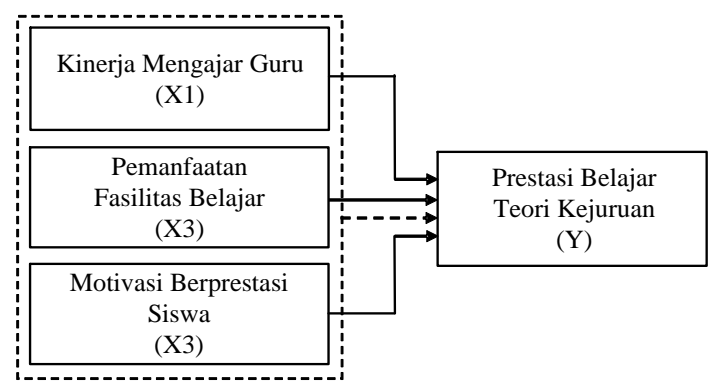

Gambar 1. Desain Penelitian

Penelitian ini dilaksanakan pada bulan Januari - Februari 2013 di SMK se Kota Yogyakarta Kompetensi Keahlian Teknik Instalasi Tenaga Listrik. Populasi penelitian ini adalah seluruh siswa kelas XII Kompetensi Keahlian Teknik Instalasi Tenaga Listrik tahun pelajaran 2012/2013 yang berjumlah 294 siswa.

Pengambilan sampel dalam penelitian ini menggunakan teknik probability sampling dengan tipe teknik proportional random sampling. Probability sampling merupakan teknik pengambilan sampel yang memberikan peluang yang sama bagi setiap unsur (anggota) populasi untuk dipilih menjadi anggota sampel (Sugiyono, 2011: 92). Penentuan sampel dengan teknik proportional random sampling dilakukan dengan mengambil sampel dari tiap-tiap sub populasi dengan memperhitungkan besar kecilnya sub-sub populasi 
tersebut. Cara tersebut dapat memberi landasan generalisasi yang lebih dapat dipertanggungjawabkan dari pada tidak memperhitungkan besar kecilnya sub populasi dari tiap-tiap sub populasi

Ukuran pengambilan sampel ditentukan dengan mengacu mengacu pada rumus Slovin (Husein Umar, 1999: 78), sehingga diperoleh jumlah 170 siswa. Sebaran sampel pada masing-masing sekolah disajikan pada Tabel 1.

Tabel 1. Jumlah Sampel Penelitian

\begin{tabular}{clcc}
\hline No & Nama Sekolah & \multicolumn{2}{c}{$\Sigma$ Siswa $\Sigma$ Sampel } \\
\hline 1 & SMK N 2 Yogyakarta & 115 & 67 \\
2 & SMK N 3 Yogyakarta & 122 & 71 \\
3 & SMK Muh. 3 Yogyakarta & 26 & 15 \\
4 & SMK Piri 1 Yogyakarta & 15 & 8 \\
5 & SMK Taman Siswa & 16 & 9 \\
& Jumlah total & 294 & 170 \\
\hline
\end{tabular}

Teknik pengumpulan data penelitian menggunakan kuesioner tertutup dan soal teori kejuruan. Kuesioner digunakan untuk mengambil data pada variabel independen $(\mathrm{X})$, sedangkan instrumen yang digunakan untuk mengambil data prestasi belajar adalah soal teori kejuruan teknik instalasi tenaga listrik yang disusun berdasarkan kisi-kisi dari BSNP.

Kuesioner disusun berdasarkan indikator pada setiap variabel. Indikator pada variabel kinerja mengajar guru $\left(\mathrm{X}_{1}\right)$ antara lain: membuka pelajaran, menjelaskan materi pelajaran, menguasai bahan ajar, menguasai metode, keterampilan menggunakan media, keterampilan guru untuk bertanya pada siswa, tingkah laku guru dalam pembelajaran, kemampuan penilaian guru dalam pembelajaran, dan menutup pelajaran.

Indikator pada variabel pemanfaatan fasilitas belajar $\left(\mathrm{X}_{2}\right)$ antara lain: pemanfaatan alat pelajaran, pemanfaatan alat peraga, pemanfaatan media pembelajaran, pemanfaatan ruang kelas, pemanfaatan ruang praktek dan pemanfaatan ruang perpustakaan. Indikator pada variabel motivasi berprestasi siswa $\left(\mathrm{X}_{3}\right)$ antara lain: rajin belajar dengan penuh semangat, mempunyai keinginan untuk berprestasi, tekun dalam menyelesaikan tugas, memiliki rasa percaya diri, memiliki jiwa mandiri dan memiliki tanggung jawab pribadi.
Kuesioner sebelum digunakan untuk pengambilan data penelitian diujicobakan pada siswa kelas XII Teknik Instalasi Tenaga Listrik di SMK Negeri 1 Sedayu Bantul yang berjumlah 32 siswa. Tujuan ujicoba adalah untuk mengetahui validitas dan reliabilitas instrumen secara empirik. Analisis validitas kuesioner ditentukan dengan korelasi product moment dari Pearson, sedangkan reliabilitas instrumen menggunakan rumus Alpha. Hasil analisis ujicoba instrumen berupa kuesioner disajikan pada Tabel 2.

Tabel 2. Hasil Ujicoba Kuesioner

\begin{tabular}{|c|c|c|c|c|c|}
\hline No & $\begin{array}{l}\text { Variabel } \\
\text { Penelitian }\end{array}$ & $\Sigma$ & $\begin{array}{r}\mathrm{Va} \\
\text { Valid }\end{array}$ & $\begin{array}{l}\text { itas } \\
\text { avalid }\end{array}$ & Reliabilitas \\
\hline 1 & $\begin{array}{l}\text { Kinerja } \\
\text { Mengajar }\end{array}$ & 36 & 27 & 9 & 0,930 \\
\hline 2 & $\begin{array}{l}\text { Pemanfaatan } \\
\text { Fasilitas }\end{array}$ & 33 & 26 & 7 & 0,839 \\
\hline 3 & $\begin{array}{l}\text { Motivasi } \\
\text { Berprestasi }\end{array}$ & 33 & 22 & 11 & 0,834 \\
\hline
\end{tabular}

Instrumen berupa soal teori kejuruan juga diujicobakan kepada siswa kelas XII Teknik Instalasi Tenaga Listrik di SMK Negeri 1 Sedayu Bantul yang berjumlah 32 sis-wa, kemudian dilakukan analisis butir soal. Menurut Anastasi dan Urbina (1997: 184) tujuan utama analisis butir soal dalam sebuah tes adalah untuk mengidentifikasi kekurangan-kekurangan dalam tes dalam pembelajaran. Analisis butir soal yang dilakukan dengan pendekatan teori klasik.

Menurut Millman dan Greene (1993: 358) dalam Depdiknas (2008: 8), analisis butir soal secara klasik adalah proses penelaahan butir soal melalui informasi dari jawaban peserta didik guna meningkatkan mutu butir soal yang bersangkutan dengan menggunakan teori tes klasik. Kelebihan analisis butir soal secara klasik adalah murah, dapat dilaksanakan sehari-hari dengan cepat menggunakan komputer, sederhana, familier dan dapat menggunakan data dari beberapa peserta didik atau sampel kecil. Tujuan analisis butir soal pada soal teori kejuruan menggunakan pendekatan teori klasik untuk mengetahui tingkat kesukaran soal, daya beda soal, dan berfungsi tidaknya pengecoh soal dengan bantuan program ITEMAN. Hasil analisis butir soal teori kejuruan ditunjukkan seperti pada Tabel 3. 
Tabel 3. Rangkuman Hasil Analisis Butir Soal

\begin{tabular}{cccc}
\hline No & Hasil Analisis & Jumlah & Persentase \\
\hline 1 & Butir soal diterima & 9 & 0,18 \\
2 & Butir soal direvisi & 31 & 0,62 \\
3 & Butir soal dibuang & 10 & 0,20 \\
& Jumlah & 50 & 100 \\
\hline
\end{tabular}

Instrumen yang dinyatakan valid kemudian digunakan untuk pengambilan data penelitian pada siswa kelas XII Teknik Instalasi Tenaga Listrik di SMK se-Kota Yogyakarta pada tahun pelajaran 2012/2013 yang berjumlah 170 siswa.

Hasil analisis kemudian digunakan untuk menjawab hipotesis penelitian. Analisis uji hipotesis pada penelitian ini menggunakan analisis regresi. Menurut Sofyan Yamin (2011: 2), analisis regresi merupakan sebuah metode statistik yang berguna untuk memodelkan fungsi hubungan antara variabel dependen dengan variabel independen. Setiap perubahan nilai atau skor pada variabel dependen bergantung pada perubahan variabel independen. Analisis regresi yang digunakan pada penelitian ini adalah analisi regresi linier sederhana dan regresi linier ganda.

Analisi regresi linier sederhana digunakan untuk mengetahui ada tidaknya pengaruh secara parsial antara masing-masing variabel independen terhadap variabel dependen, sedangkan regresi linier ganda digunakan untuk mengetahui ada tidaknya pengaruh secara simultan atau bersama-sama antara semua variabel independen terhadap variabel dependen. Uji signifikansi regresi linier sederhana ditentukan dengan uji statistik t (Uji t), sedangkan uji signifikansi regresi linier ganda ditentukan dengan uji statistik F (Uji F).

Sebelum dilakukan analisis regresi ganda, maka terlebih dahulu dilakukan uji prasyarat atau asumsi klasik.Hal tersebut dikarenakan, model regresi yang baik adalah regresi yang memenuhi uji prasyarat atau uji asumsi klasik tersebut. Uji asumsi klasik atau uji prasyarat pada penelitian ini terdiri dari uji normalitas, uji multikolinieritas, uji autokorelasi, uji heteroskedastisitas dan uji linieritas. Analisi regresi dan uji asumsi klasik pada penelitian ini menggunakan bantuan program SPSS versi 16.0.

\section{HASIL DAN PEMBAHASAN}

\section{Kinerja mengajar guru}

Menurut Jones, Jenkin dan Lord (2006: 3), kinerja didefinisikan sebagai "performance means both behaviours and result, behaviours emanate from the performer and transform performance from abstraction to action". Kinerja didefinisikan sebagai bentuk perilaku dan hasil, perilaku muncul dari seseorang kemudian merubah dari yang abstrak menjadi tindakan. Berdasarkan definisi tersebut, maka kinerja mengajar guru menunjukkan kegiatan yang dilakukan oleh guru selama pembelajaran yang dapat diamati oleh siswa.

Penilaian kinerja mengajar guru oleh siswa menunjukkan hasil pengamatan siswa selama pembelajaran baik pada saat guru membuka pelajaran, melaksanakan pembelajaran, mengevaluasi dan menutup pelajaran. Kegiatan tersebut hampir setiap hari dilakukan oleh guru didalam pembelajaran dan dapat diamati oleh seluruh siswa yang mengikuti pembelajaran. Oleh karena itu, penilaian kinerja mengajar guru dapat digunakan untuk mengetahui seberapa baik guru melakukan pekerjaan mereka (Griffin, 2004: 429). Siswa merupakan responden yang berinteraksi dengan guru selama pembelajaran berlangsung, sehingga akan mampu mengamati kegiatan guru.

Berdasarkan analisis deskriptif variabel kinerja mengajar guru $\left(\mathrm{X}_{1}\right)$ diperoleh bahwa rata-rata (mean) sebesar 108,71, simpangan baku (standard deviasi) sebesar 12,33, nilai minimal 73 dan nilai maksimal 135. Distribusi frekuensi dari variabel kinerja mengajar guru (X1) dapat dilihat pada Tabel.

Tabel 4. Distribusi Frekuensi Variabel X1

\begin{tabular}{clcc}
\hline Kelas Interval Kriteria & \multicolumn{2}{c}{ Frekuensi Persentase } \\
\hline $124-136$ & Sangat tinggi & 25 & 14,71 \\
$111-123$ & Tinggi & 44 & 25,88 \\
$98-110$ & Sedang & 71 & 41,76 \\
$85-97$ & Rendah & 27 & 15,88 \\
$72-84$ & Sangat & 3 & 3 \\
& rendah & & 100 \\
\hline
\end{tabular}

Berdasarkan tabel 4 di atas, maka dapat disimpulkan bahwa variabel kinerja mengajar guru pada kelas interval 98-110 mempunyai frekuensi yang paling tinggi yaitu 71 dengan 
persentase sebesar $41,76 \%$. Hal tersebut menunjukkan bahwa siswa yang memberikan jawaban dengan skor 98-110 mempunyai frekuensi yang paling tinggi. Oleh karena itu dapat disimpulkan bahwa kinerja mengajar guru masuk dalam kategori sedang. Apabila digambarkan dalam diagram batang adalah sebagai berikut:

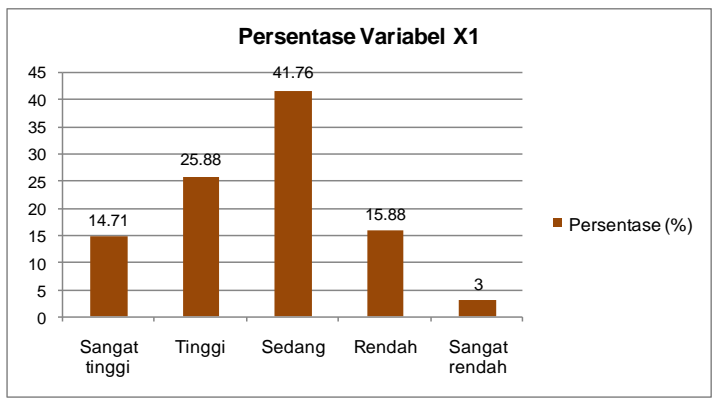

Gambar 2. Diagram Batang Variabel $\mathrm{X}_{1}$

Hasil analisis distribusi frekuensi terhadap kinerja mengajar guru menunjukkan bahwa kinerja mengajar guru berada dalam kategori sedang. Hal tersebut dikarenakan, guru produktif yang mengampu mata diklat kejuruan tidak hanya mengampu teori kejuruan saja, tetapi sebagian besar waktunya digunakan untuk melaksanakan kegiatan di bengkel atau laboratorium. Hal tersebut sesuai dengan pendapat Soeprijanto (2010: 38) yang menyebutkan bahwa kinerja guru praktik menurut merupakan perilaku guru pada saat menjalani tugas pembelajaran mulai dari perencanaan, persiapan, pelaksanaan pembelajaran praktik, dan pengadministrasian sarana praktik. Tugas tersebut jika diamati tidak hanya terfokus pada kegiatan mengajar saja, tetapi tugas-tugas lain di laboratorium/ bengkel praktik.

\section{Pemanfaatan fasilitas belajar}

Fasilitas belajar atau sering disebut sarana dan prasarana belajar merupakan komponen pokok dalam pembelajaran. Hal tersebut sesuai dengan pendapat Nana Sudjana (2005: 30) yang menyebutkan bahwa setidaknya ada empat komponen pokok yang harus dipenuhi dalam proses belajar mengajar yaitu tujuan, bahan, metode dan alat serta penilaian. Metode dan alat pengajaran merupakan salah satu fasilitas yang berfungsi sebagai jembatan atau media transformasi pelajaran terhadap tujuan yang ingin dicapai.

Menurut Permendiknas No. 40 Tahun 2008 (2008: 2), yang dimaksud dengan sarana adalah perlengkapan pembelajaran yang dapat dipindah-pindah, sedangkan prasarana adalah fasilitas dasar untuk menjalankan fungsi Sekolah Menengah Kejuruan/Madrasah Aliyah Kejuruan (SMK/MAK). Sarana maupun prasarana sangat dibutuhkan dalam pembelajaran. Permendiknas No. 40 Tahun 2008 merupakan Peraturan Menteri Pendidikan Nasional yang mengatur standar sarana dan prasarana di SMK/MAK.

Berdasarkan analisis deskriptif pada variabel pemanfaatan fasilitas belajar $\left(\mathrm{X}_{2}\right)$ diperoleh bahwa rata-rata (mean) sebesar 90,60, simpangan baku (standard deviasi) sebesar 12,57, nilai min 57 dan nilai maks 121 . Distribusi frekuensi dari variabel pemanfaatan fasilitas belajar $\left(\mathrm{X}_{2}\right)$ dapat dilihat pada tabel 4 di bawah ini.

Tabel 5. Distribusi Frekuensi Variabel $\mathrm{X}_{2}$

\begin{tabular}{clcc}
\hline Kelas Interval Kriteria & Frekuensi & Persentase \\
\hline $109-121$ & Sangat tinggi & 14 & 8,24 \\
$96-108$ & Tinggi & 43 & 25,29 \\
$83-95$ & Sedang & 75 & 44,12 \\
$70-82$ & Rendah & 28 & 16,47 \\
$57-69$ & Sangat & 10 & 5,88 \\
& rendah & & \\
\hline & Jumlah & 170 & 100 \\
\hline
\end{tabular}

Berdasarkan tabel 5, maka dapat disimpulkan bahwa variabel pemanfaatan fasilitas belajar pada kelas interval 83-95 mempunyai frekuensi yang paling tinggi yaitu 75 dengan persentase sebesar $44,12 \%$. Oleh karena itu dapat disimpulkan bahwa variabel pemanfaatan fasilitas belajar masuk dalam kategori sedang. Apabila digambarkan dalam diagram batang adalah sebagai berikut:

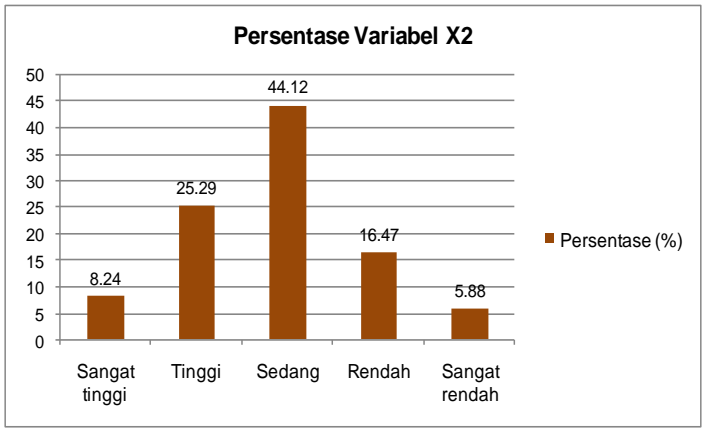

Gambar 3. Diagram Batang Variabel $\mathrm{X}_{2}$ 
Fasilitas belajar yang dimanfaatkan dengan optimal dalam pembelajaran akan memudahkan proses pembelajaran yang dilakukan oleh guru. Bagi siswa, pemanfaatan fasilitas dengan optimal akan mampu memudahkan dalam memahami pembelajaran dari guru. Oleh karena itu, selain kelengkapan dan fasilitas belajar, pemanfaatan fasilitas belajar juga menjadi bagian yang terpenting dalam pembelajaran. Artinya semakin tinggi tingkat pemanfaatan fasilitas pembelajaran, maka proses belajar mengajar dapat berjalan dengan lancar dan berkualitas, sehingga prestasi belajar siswa akan dapat meningkat.

\section{Motivasi Berprestasi Siswa}

Motivasi berprestasi siswa dalam pembelajaran akan memudahkan proses pembelajaran yang dilakukan di dalam kelas. Bagi siswa, motivasi berprestasi akan mendorong dirinya untuk selalu bersemangat didalam belajar. Hal tersebut sesuai pendapat Nicholls (1979) dalam Alderman (2004: 11) yang menyebutkan bahwa "optimum motivation as one that provides the greatest degree of intellectual development", motivasi yang tinggi merupakan salah satu aspek terhadap perkembangan intelektual seseorang.

Menurut Aydin dan Coşkun (2011: 122) motivasi berprestasi didefinisikan sebagai "achievement motivation can be defined as making good business or the orientation to the actions which is important to compel with the perfect standards". Motivasi berprestasi adalah melakukan usaha yang baik atau berorientasi ke arah tindakan yang penting sesuai dengan standar terbaik. Oleh karena itu, siswa yang mempunyai motivasi berprestasi yang tinggi akan melakukan usaha yang keras sesuai tujuan atau standar yang akan dicapai.

Berdasarkan analisis deskriptif pada variabel motivasi berprestasi siswa $\left(\mathrm{X}_{3}\right)$ diperoleh bahwa rata-rata (mean) sebesar 88,49, simpangan baku (standard deviasi) sebesar 8,80 , nilai min 53 dan nilai maks 106. Berdasarkan data tersebut, maka distribusi frekuensi dari variabel $\mathrm{X}_{3}$ disajikan pada Tabel 6 .

Berdasarkan tabel 6, maka dapat disimpulkan bahwa variabel motivasi berprestasi siswa pada kelas interval 85-95 mempunyai frekuensi yang paling tinggi yaitu 78 dengan persentase sebesar $45,88 \%$. Oleh karena itu dapat disimpulkan bahwa motivasi berprestasi siswa masuk dalam kategori tinggi. Apabila digambarkan dalam diagram batang seperti pada Gambar 4.

Tabel 6. Distribusi Frekuensi Variabel $\mathrm{X}_{3}$

\begin{tabular}{clcc}
\hline Kelas Interval Kriteria & Frekuensi & Persentase \\
\hline $96-106$ & Sangat tinggi & 38 & 22,35 \\
$85-95$ & Tinggi & 78 & 45,88 \\
$74-84$ & Sedang & 46 & 27,06 \\
$63-73$ & Rendah & 7 & 4,12 \\
$52-62$ & Sangat & 1 & 0,59 \\
& rendah & 170 & 100 \\
\hline
\end{tabular}

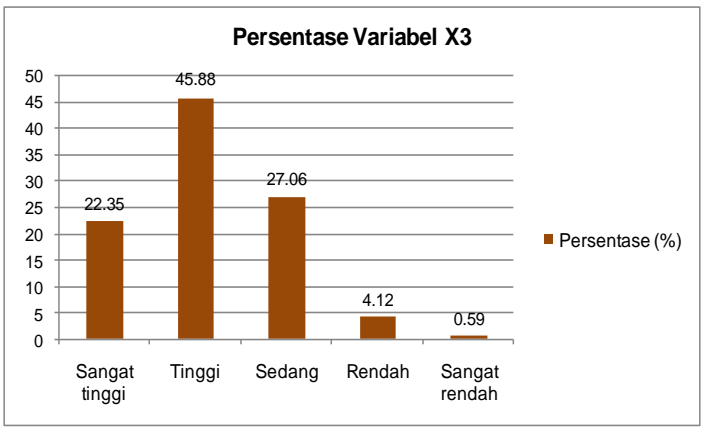

Gambar 4. Diagram Batang Variabel $\mathrm{X}_{3}$

\section{Prestasi belajar teori kejuruan}

Pengembangan soal teori kejuruan Teknik Instalasi Tenaga Listrik dilakukan dengan cara melakukan analisis butir soal secara kualitatif dan kuantitatif. Hal ini sesuai dengan pendapat dari Anastasi dan Urbina (1997: 172) yang menyebutkan bahwa terdapat dua cara yang dapat digunakan untuk menganalisis butir soal yaitu analisis soal secara kualitatif dan kuantitatif. Menurut Popham (1995: 195), analisis butir soal secara kualitatif dapat dilakukan dengan prosedur peningkatan secara judgment, sedangkan analisis secara kuantitatif dapat dilakukan dengan prosedur peningkatan secara empirik.

Analisis soal teori kejuruan secara kualitatif pada penelitian ini dilakukan dengan melakukan judgement atau meminta pendapat dan masukan terhadap 3 orang ahli yaitu 2 orang dosen dan satu guru SMK yang mengajar Teknik Instalasi Tenaga Listrik. Tujuannya adalah untuk mengetahui layak atau tidaknya sebuah soal sebelum diujicobakan dari segi isinya. Setelah dilakukan analisis kualitatif terhadap 50 butir soal teori kejuruan Teknik Instalasi Tenaga Listrik maka soal dinya- 
takan layak untuk diujicobakan dengan beberapa masukan dan saran dari para ahli untuk diperbaiki.

Selain melakukan analisis kualitatif terhadap soal teori kejuruan, juga dilakukan analisis secara empirik dengan ujicoba instrumen. Ujicoba soal teori kejuruan dilaksanakan pada siswa kelas XII Teknik Instalasi Tenaga Listrik SMK Negeri 1 Sedayu Bantul yang berjumlah 32 siswa. Tujuannya adalah untuk mengetahui tingkat kesukaran soal, daya pembeda soal, efektifitas distraktor, dan reliabilitas soal. Analisis butir soal teori kejuruan pada penelitian ini dilakukan dengan pendekatan teori klasik dengan bantuan program ITEMAN.

Berdasarkan hasil analisis kuantitatif untuk tingkat kesukaran soal menyebutkan bahwa sebanyak 14 butir soal termasuk soal dengan klasifikasi sukar, 14 butir soal termasuk soal dengan klasifikasi sedang atau baik, dan 22 butir soal termasuk soal dengan klasifikasi mudah. Menurut Suharsimi (2012: 222) soal yang baik adalah soal yang tidak terlalu mudah atau tidak terlalu sukar. Soal yang terlalu mudah tidak merangsang siswa untuk mempertinggi usaha memecahkannya. Sebaliknya soal yang terlalu sukar akan menyebabkan siswa menjadi putus asa dan tidak mempunyai semangat untuk mencoba lagi karena diluar jangkauannya. Berdasarkan tingkat kesukaran soal, dari 50 butir soal teori kejuruan yang diujicobakan, maka soal yang memiliki tingkat kesukaran yang baik berjumlah 14 butir soal.

Hasil analisis kuantitatif untuk daya beda soal diperoleh 37 butir soal termasuk dalam kategori soal dengan daya beda baik dan 13 butir soal termasuk dalam kategori soal dengan daya beda kurang baik. Menurut Suharsimi (2012: 226) daya pembeda soal adalah kemampuan sesuatu soal untuk membedakan antara siswa yang pandai (berkemampuan tinggi) dengan siswa yang bodoh (berkemampuan rendah). Apabila suatu soal dapat dijawab benar oleh siswa pandai maupun siswa bodoh atau tidak dapat dijawab benar oleh siswa pandai maupun siswa bodoh, maka soal itu tidak baik karena tidak mempunyai daya pembeda. Oleh karena itu soal yang baik adalah soal yang dapat dijawab benar oleh siswa-siswa yang pandai saja. Berdasarkan analisis butir soal dengan ITEMAN, maka dari 50 soal yang diujicobakan, jumlah soal yang mempunyai daya pembeda yang baik berjumlah 37 butir soal.

Hasil analisis kuantitatif untuk efektifitas distraktor diperoleh bahwa dari 50 soal teori kejuruan yang diujicobakan, soal yang distraktornya berfungsi berjumlah 9 butir, sedangkan 41 butir soal yang lain distraktornya tidak berfungsi. Menurut Suharsimi (2012: 234) suatu distraktor dapat dikatakan berfungsi baik apabila paling sedikit dipilih oleh $5 \%$ peserta tes. Oleh karena itu dapat disimpulkan bahwa dari 50 soal yang diujikan, ada 9 soal yang memiliki distraktor baik karena distraktor dari 9 soal tersebut dipilih oleh minimal $5 \%$ peserta tes, sedangkan sebanyak 41 soal belum memiliki distraktor yang baik, karena distraktor belum dipilih oleh $5 \%$ dari peserta tes.

Nilai reliabilitas soal teori kejuruan yang diujicoba adalah 0,861. Menurut Suharsimi (2002: 164) suatu soal dikatakan reliabel apabila nilai reliabilitasnya lebih besar dari nilai r product-moment. Nilai reliabilitas soal teori kejuruan sebesar 0,874 menunjukkan bahwa soal teori kejuruan sudah dapat dikatakan sebagai soal yang reliabel dikarenakan nilai reliabilitas apabila dikonsultasikan dengan $\mathrm{r}$ product-moment nilainya lebih besar $(0,874>0,349)$. Oleh karena itu dengan nilai reliabilitas sebesar 0,861 dapat disimpulkan bahwa soal teori kejuruan mempunyai reliabilitas yang sangat tinggi, sehingga soal teori kejuruan tersebut sudah memiliki kualitas yang baik sebagai instrumen pengumpul data penelitian.

Analisis soal teori kejuruan juga dilakukan untuk mendeskripsikan nilai teori kejuran. Hasil analisis deskriptif menunjukkan bahwa rata-rata (mean) sebesar 60,24, simpangan baku (standard deviasi) sebesar 8,84, nilai min 33 dan nilai maks 80. Berdasarkan data tersebut, maka distribusi frekuensi dari nilai teori kejuruan adalah sebagai berikut.

Tabel 7. Distribusi Frekuensi Variabel Y

\begin{tabular}{|c|c|c|c|}
\hline \multicolumn{2}{|c|}{ Kelas Interval Kriteria } & \multirow{2}{*}{$\begin{array}{c}\text { Frekuensi } \\
15\end{array}$} & \multirow{2}{*}{$\begin{array}{c}\text { Persentase } \\
8,82\end{array}$} \\
\hline $72-81$ & Sangat tinggi & & \\
\hline $62-71$ & Tinggi & 60 & 35,29 \\
\hline $52-61$ & Sedang & 68 & 40,00 \\
\hline $42-51$ & Rendah & 23 & 13,53 \\
\hline \multirow[t]{2}{*}{$32-41$} & Sangat rendah & 4 & 2,35 \\
\hline & Jumlah & 170 & 100 \\
\hline
\end{tabular}


Data pada variabel prestasi belajar teori kejuruan (Y) merupakan hasil nilai teori kejuruan siswa kelas XII Kompetensi Keahlian Teknik Instalasi Tenaga Listrik di SMK Kota Yogyakarta. Soal teori kejuruan yang diujikan kepada siswa adalah soal pilihan ganda yang berjumlah 40 butir dengan 5 alternatif jawaban. Responden adalah siswa kelas XII Teknik Instalasi Tenaga Listrik di SMK se Kota Yogyakarta dengan jumlah sampel 170 siswa.

Berdasarkan tabel 6 di atas, maka dapat disimpulkan bahwa variabel prestasi belajar siswa pada kelas interval 52-61 mempunyai frekuensi yang paling tinggi yaitu 68 dengan persentase sebesar $40 \%$. Oleh karena itu dapat disimpulkan bahwa nilai teori kejuruan siswa masuk dalam kategori sedang. Apabila digambarkan secara visual dalam diagram batang adalah sebagai berikut:

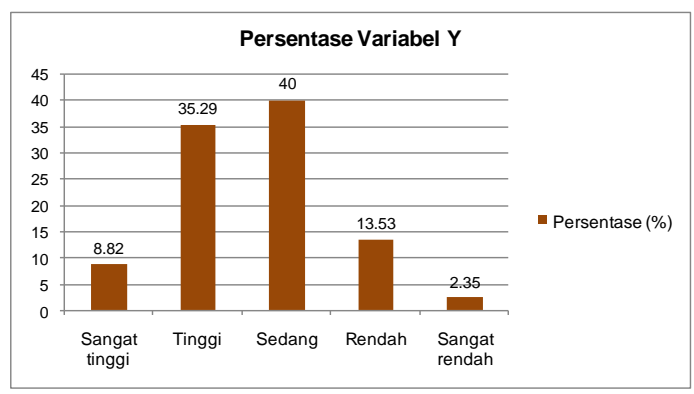

Gambar 5. Diagram Batang Variabel Y

Analisis deskriptif pada penelitian ini kemudian digunakan untuk analisis regresi yang bertujuan untuk mengetahui pengaruh antara variabel independen (X) terhadap variabel dependen $(\mathrm{Y})$.

\section{Analisis uji asumsi klasik}

Sebelum dilakukan analisis regresi ganda, maka terlebih dahulu dilakukan uji prasyarat atau asumsi klasik. Uji asumsi klasik atau uji prasyarat pada penelitian ini terdiri dari uji normalitas, uji multikolinieritas, uji autokorelasi, uji heteroskedastisitas dan uji linieritas. Hasil analisis uji asumsi klasik pada penelitian ini adalah sebagai berikut:

a) Data untuk variabel kinerja mengajar guru $\left(\mathrm{X}_{1}\right)$, pemanfaatan fasilitas belajar $\left(\mathrm{X}_{2}\right)$, motivasi berprestasi siswa $\left(\mathrm{X}_{3}\right)$ dan prestasi belajar teori kejuruan Teknik Instalasi Tenaga Listrik (Y) semuanya berdistribusi normal. b) Model regresi linier berganda terbebas dari autokorelasi karena nilai nilai DW $(1,861)$ berada diantara daerah $\mathrm{du}=$ 1,7851 dan 4-dl=2,2866 atau berada pada daerah yang tidak ada autokorelasinya.

c) Model regresi linier berganda terbebas dari gejala multikolinieritas dikarenakan nilai VIF untuk semua variabel lebih kecil dari 10 dengan nilai toleransinya mendekati 1.

d) Model regresi linier berganda terbebas dari heteroskedastisitas dikarenakan gambar grafik graft scatter plot menunjukkan pola penyebaran pada titiktitiknya dan tidak membentuk suatu pola tertentu dan pada Uji Glejser menunjukkan bahwa semua nilai signifykansi dari ketiga variabel lebih kecil dari 0,05 .

e) Semua variabel bebas $\left(X_{1}, X_{2}\right.$ dan $\left.X_{3}\right)$ mempunyai hubungan yang linier (linieritas) terhadap variabel terikat $(\mathrm{Y})$ karena mempunyai mempunyai nilai signifikasi (sig.) yang lebih besar dari 0.05 .

Berdasarkan keterangan di atas, maka model regresi linier berganda pada penelitian ini memenuhi asumsi klasik, sehingga dapat dilanjutkan untuk analisis regresi berganda untuk menguji hipotesis linier ganda.

\section{Pengaruh Kinerja Mengajar Guru terhadap Prestasi Belajar Teori Kejuruan.}

Berdasarkan analisis regresi linier sederhana antara variabel kinerja mengajar guru $\left(\mathrm{X}_{1}\right)$ dengan prestasi belajar $(\mathrm{Y})$ maka diperoleh besar nilai $\mathrm{t}_{\text {hitung }}=9,047>\mathrm{t}_{\text {tabel }}=$ 1,654 sehingga dapat disimpulkan bahwa variabel kinerja mengajar guru $\left(\mathrm{X}_{1}\right)$ mempunyai pengaruh yang positif dan signifikan terhadap prestasi belajar teori kejuruan.

Besarnya pengaruh ditunjukkan dengan nilai koefisien determinasi $\mathrm{R}^{2}$ sebesar 0,328 . Hal tersebut mengandung pengertian bahwa pengaruh variabel kinerja mengajar adalah $32,8 \%$, sedangkan $67,2 \%(100 \%-32,8 \%)$ dipengaruhi oleh variabel lain selain variabel $\mathrm{X}_{1}$. Persamaan garis regresinya adalah $\mathrm{Y}=$ $15,851+0,408 \mathrm{X}_{1}$. Hal tersebut mengandung pengertian bahwa setiap kali variabel kinerja mengajar guru $\left(\mathrm{X}_{1}\right)$ bertambah satu, maka rata-rata prestasi belajar (Y) bertambah 0,408 . 
Hasil penelitian tersebut sejalan dengan studi yang dilakukan Heynemen \& Loxley pada tahun 1983 di 29 negara menemukan bah-=wa diantara berbagai masukan (input) yang menentukan pendidikan (yang ditunjukkan oleh prestasi belajar) sepertiganya ditentukan oleh guru (Dedi Supriadi, 1998: 178). Hal tersebut dikarenakan semua yang disiapkan dalam pendidikan oleh sekolah baik berupa sarana dan prasarana, biaya dan kurikulum, hanya akan berarti jika diberi arti oleh guru.

Hasil studi tersebut sejalan juga dengan pendapat Uzer Usman (2002: 9) yang menyebutkan bahwa proses belajar mengajar dan hasil belajar siswa sebagian besar ditentukan oleh peranan dan kompetensi guru. Oleh karena itu kinerja guru merupakan faktor yang dapat berpengaruh terhadap peningkatan prestasi belajar siswa, dikarenakan interaksi antara guru dengan siswa berlangsung selama pembelajaran berlangsung.

\section{Pengaruh Pemanfaatan Fasilitas Belajar terhadap Prestasi Belajar Teori Kejuruan.}

Berdasarkan analisis regresi linier sederhana antara variabel pemanfatan fasilitas belajar $\left(\mathrm{X}_{2}\right)$ dengan prestasi belajar $(\mathrm{Y})$ maka diperoleh besar nilai $\mathrm{t}_{\text {hitung }}=4,087>\mathrm{t}_{\text {tabel }}=$ 1,654 sehingga dapat disimpulkan bahwa variabel pemanfatan fasilitas belajar $\left(\mathrm{X}_{2}\right)$ mempunyai pengaruh yang signifikan terhadap prestasi belajar teori kejuruan.

Besarnya pengaruh ditunjukkan dengan nilai koefisien determinasi $\mathrm{R}^{2}$ sebesar 0,090 . Hal tersebut mengandung pengertian bahwa pengaruh pemanfatan fasilitas belajar adalah 9\%, sedangkan $91 \%$ (100\% - 9\%) dipengaruhi oleh variabel lain selain variabel $\mathrm{X}_{2}$. Persamaan garis regresinya adalah $\mathrm{Y}=41,159+$ $0,210 \mathrm{X}_{2}$. Hal tersebut mengandung pengertian bahwa setiap kali variabel pemanfatan fasilitas belajar $\left(\mathrm{X}_{2}\right)$ bertambah satu, maka rata-rata prestasi belajar $(\mathrm{Y})$ bertambah 0,210.

Tingkat pemanfaatan fasilitas belajar yang ada pada pembelajaran teori kejuruan diharapkan dapat mengoptimalkan proses belajar mengajar. Hal tersebut sesuai dengan pendapat Nana Sudjana (2005: 99), yang menyebutkan bahwa alat peraga dalam mengajar memegang peranan penting sebagai alat bantu untuk menciptakan proses belajar mengajar yang efektif.
Pemanfaatan fasilitas belajar yang adalah media pembelajaran. Menurut Azhar Arsyad (2007: 2-3) media adalah bagian yang tidak terpisahkan dari proses belajar mengajar demi tercapainya tujuan pendidikan pada umumnya dan tujuan pembelajaran di sekolah pada khususnya. Oleh karena itu pemanfaatan fasilitas belajar merupakan bagian penting dan tidak dapat dipisahkan dalam proses belajar mengajar di sekolah. Pada umumnya sekolah sudah banyak memiliki fasilitas belajar yang cukup memadai, sehingga dibutuhkan peran dari guru dan siswa untuk memanfaatkannya.

\section{Pengaruh Motivasi Berprestasi Siswa terhadap Prestasi Belajar Teori Kejuruan.}

Pengaruh motivasi berprestasi siswa terhadap prestasi belajar teori kejuruan dapat dilihat secara statistik melalui analisis regresi linier sederhana menggunakan Uji t. Berdasarkan analisis regresi linier sederhana antara variabel motivasi berprestasi siswa $\left(\mathrm{X}_{3}\right)$ dengan prestasi belajar (Y) maka diperoleh besar nilai $\mathrm{t}_{\text {hitung }}=5,256>\mathrm{t}_{\text {tabel }}=1,654$ sehingga dapat disimpulkan bahwa variabel motivasi berprestasi siswa $\left(\mathrm{X}_{3}\right)$ mempunyai pengaruh yang signifikan terhadap prestasi belajar teori kejuruan.

Besarnya pengaruh ditunjukkan dengan nilai koefisien determinasi $\mathrm{R}^{2}$ sebesar 0,141. Hal tersebut mengandung pengertian bahwa pengaruh variabel motivasi berprestasi siswa adalah $14,1 \%$, sedangkan $85,9 \%$ (100\% $14,1 \%$ ) dipengaruhi oleh variabel lain selain variabel $\mathrm{X}_{3}$. Persamaan garis regresinya adalah $\mathrm{Y}=27,010+0,375 \mathrm{X}_{3}$. Hal tersebut mengandung pengertian bahwa setiap kali variabel motivasi berprestasi siswa $\left(X_{3}\right)$ bertambah satu, maka rata-rata prestasi belajar (Y) bertambah 0,375.

Motivasi berprestasi siswa dalam pembelajaran akan memudahkan proses pembelajaran yang dilakukan di dalam kelas. Bagi siswa, motivasi berprestasi akan mendorong dirinya untuk semangat didalam belajar. Hal tersebut sesuai pendapat Nicholls (1979) dalam Alderman (2004: 11) yang menyebutkan bahwa "optimum motivation as one that provides the greatest degree of intellectual development", motivasi yang tinggi merupakan salah satu aspek terhadap perkembangan intelektual seseorang.

Bagi seorang guru di sekolah, motivasi berprestasi siswa akan memudahkan penyam- 
paian pembelajaran kepada siswa, daya serap menjadi lebih tinggi sehingga prestasi belajar siswa juga akan meningkat. Oleh karena itu motivasi berprestasi sangat berperan dalam pembelajaran, dikarenakan semakin tinggi motivasi berprestasi siswa, maka semangat siswa untuk belajar juga meningkat.

Hasil analisis yang menunjukkan bahwa motivasi berprestasi mempunyai pengeruh terhadap prestasi belajar teori kejuruan juga sejalan dengan teori kebutuhan yang dikembangkan oleh David C. McClelland. Menurut David C. McClelland dalam Gibson dan et al. (2009: 135) terdapat tiga kebutuhan seseorang yaitu: 1) kebutuhan akan prestasi (need of achievement) disingkat $n$ Ach, 2) kebutuhan akan afiliasi (need of affiliation) disingkat $n$ Aff, dan 3) kebutuhan akan kekuasaan (need of power) disingkat $n$ Pow. Kebutuhan akan prestasi adalah dorongan dari dalam diri untuk mengatasi segala tantangan dan hambatan dalam upaya mencapai tujuan. Motivasi berprestasi yang ditunjukkan oleh siswa menunjukkan bahwa kebutuhan mereka akan berprestasi termasuk tinggi.

\section{Pengaruh Kinerja Guru, Pemanfaatan fasilitas belajar, dan Motivasi Berprestasi Siswa secara bersama-sama terhadap Prestasi Belajar Teori Kejuruan.}

Berdasarkan analisis regresi linier ganda antara variabel $\mathrm{X}_{1}, \mathrm{X}_{2}$, dan $\mathrm{X}_{3}$ terhadap $\mathrm{Y}$, maka diperoleh besar nilai $\mathrm{F}_{\text {hitung }}=28,899$ $>\mathrm{F}_{\text {tabel }}=2,66$ sehingga dapat disimpulkan bahwa variabel $\mathrm{X}_{1}, \mathrm{X}_{2}$, dan $\mathrm{X}_{3}$ mempunyai pengaruh yang signifikan terhadap prestasi belajar teori kejuruan.

Hasil tersebut sesuai dengan pendapat dari Murphy (2009: 22) yang menyebutkan bahwa faktor yang mempengaruhi prestasi belajar yaitu: "The extent to which educators, students, and the total educational environment reflect cultural competence significantly affects the nature and type of schooling, conditions for learning, as well as learning outcomes".

Pendapat Murphy (2009: 22) di atas menyebutkan bahwa faktor-faktor yang berpengaruh terhadap prestasi belajar diantaranya adalah pendidik, siswa dan lingkungan pendidikan yang mencerminkan budaya kompetensi. Pendidik dapat dilihat dari kinerja mengajar guru, faktor siswa dapat dipengaruhi dari motivasi berprestasi yang dimiliki dan lingkungan dapat berasal dari pemanfaatan fasilitas belajar. Oleh karena itu kinerja mengajar guru, pemanfaatan fasilitas belajar dan motivasi berprestasi siswa secara bersama-sama mempunyai pengaruh terhadap prestasi belajar teori kejuruan.

\section{SIMPULAN}

1. Terdapat pengaruh yang positif dan signifikan antara kinerja mengajar guru terhadap prestasi belajar teori kejuruan dengan besarnya pengaruh secara parsial adalah $32,8 \%$.

2. Terdapat pengaruh yang positif dan signifikan antara pemanfaatan fasilitas belajar terhadap prestasi belajar teori kejuruan dengan besarnya pengaruh secara parsial adalah $9 \%$.

3. Terdapat pengaruh yang positif dan signifikan antara motivasi berprestasi siswa terhadap prestasi belajar teori dengan besarnya pengaruh secara parsial adalah $14,1 \%$.

4. Terdapat pengaruh yang positif dan signifikan antara kinerja mengajar guru, pemanfaatan fasilitas belajar dan motivasi berprestasi siswa secara bersama-sama terhadap prestasi belajar teori kejuruan Teknik Instalasi Tenaga Listrik di SMK seKota Yogyakarta dengan besarnya pengaruh secara simultan adalah 34,3\%, sedangkan $63,7 \%$ dipengaruhi oleh faktor yang lain. Hal tersebut menunjukkan bahwa semakin kinerja mengajar guru, pemanfaatan fasilitas belajar dan motivasi berprestasi siswa maka secara bersama-sama akan memberikan peningkatan yang signifikan terhadap prestasi belajar teori kejuruaan Teknik Instalasi Tenaga Listrik di SMK se-Kota Yogyakarta.

\section{Saran}

1. Kinerja mengajar guru mempunyai pengaruh yang paling dominan terhadap prestasi belajar teori kejuruan, oleh karena itu peningkatan kinerja guru merupakan aspek penting yang harus diprioritaskan dalam peningkatan prestasi belajar siswa.

2. Fasilitas belajar di SMK dapat dimanfaatkan lebih optimal untuk mendukung kegiatan pembelajaran, sehingga materi pelajaran mudah terserap dan prestasi belajar siswa bisa meningkat. 
3. Motivasi siswa untuk berprestasi didalam pembelajaran teori kejuruan merupakan faktor pendukung dari dalam diri siswa sendiri untuk meningkatkan prestasi belajar teori kejuruan.

\section{DAFTAR PUSTAKA}

Alderman, M.K. (2004). Motivation for achievement: Possibilities for teaching and learning $\left(2^{\text {nd }} e d.\right)$. New Jersey: Lawrence Erlbaum Associates.

Anastasi, A., \& Urbina, S. (1997). Psyhological testing. $\left(7^{\text {th }} e d.\right)$. New Jersey: Prentice-Hall, Inc.

Aydın, F., \& Coşkun, M. (2011). Secondary School Students" "Achievement motivation" towards Geography Lessons. Journal of scholars research library. Karabük: Karabük University. Diambil pada tanggal 30 November 2012 dari http://scholarsresearchlibrary. com/archive.html.

Azhar Arsyad. (2007). Media pembelajaran. Jakarta: PT. RajaGrafindo Persada.

Dedi Supriadi. (1999). Mengangkat citra dan martabat guru. Yogyakarta: Adicita Karya Nusa.

Depdiknas. (2008). Panduan analisis butir soal. Direktorat Jenderal Manajemen Pendidikan Dasar dan Menengah.

Depdiknas. (2008). Permendiknas No. 40 Tahun 2008, tentang standar sarana dan prasarana di SMK/MAK.

Depdiknas. (2003). Undang-undang, Nomor 20, tahun 2003, tentang Sistem Pendidikan Nasional.

Finch, C.R., \& Crunkilton, J.R. (1999). Curriculum development in vocational and technical education: Planning, content, and implementation ( $5^{\text {th }} \mathrm{ed}$.). Boston: Allyn and Bacon.

Gibson, J.L. et al. (2009). Organizations: Behavior, structure, processes $\left(14^{\text {th }} \mathrm{ed}.\right)$. New York: McGraw-Hill.

Griffin, R.W. (2004). Manajemen (edisi ketujuh). (Terjemahan Gina Gania). Boston: Houghton Miffin. (Buku asli diterbitkan tahun 2002)
Husein Umar. (1999). Metode penelitian untuk skripsi dan tesis bisnis. Jakarta: PT. Raja Grafindo Persada.

Jones, J., \& Jenkin, M., \& Lord, S. (2006). Developing effective teacher performance. New Delhi: Paul Chapman Publishing.

Kemendiknas. (2012). Pedoman penyelenggaraan UN kompetensi keahlian SMK tahun pelajaran 2011/2012.

Murphy, P.K. (2009). Cultural competence initiative.The Arlington Public Schools. Diambil pada tanggal 13 September 2012 dari http://www.doe.virginia.gov/ special_ed/tech_asst_prof_dev/self_ass essment/disproportionality/arlington_ad apted_cultural_competence_notebook.p df

Nana Sudjana. (2005). Dasar-dasar proses belajar mengajar. Bandung: Sinar Baru Algensindo.

Popham, W.J. (1995). Classroom assessment: What teachers need to know ( $6^{\text {th }}$ ed.). Boston: Allyn and Bacon.

Soeprijanto. (2010). Pengukuran kinerja guru praktik kejuruan, konsep dan teknik pengembangan instrumen. Jakarta: CV. Tursina.

Sofyan Yamin., \& Rachmach, L.A., \& Heri Kurniawan. (2011). Regresi dan korelasi dalam genggaman anda: Aplikasi dengan software SPSS, Eviews, MINITAB, dan STATGRAPHICS. Jakarta: Penerbit Salemba Empat.

Sugiyono. (2011). Metode penelitian administrasi dilengkapi dengan metode $R \& D$. Bandung: Alfabeta.

Suharsimi Arikunto. (2012). Dasar-dasar evaluasi pendidikan. Jakarta: Bumi Aksara.

Suharsimi Arikunto. (2002). Prosedur penelitian: Suatu pendekatan praktek, Jakarta: Rineka Cipta.

Uzer Usman. (2002). Menjadi guru profesional. Bandung: PT Remaja Rosdakarya

Wardiman Djojonegoro (1998). Pengembangan sumber daya manusia: Melalui Sekolah Menengah Kejuruan (SMK) Jakata: Jayakarta Agung Ofset. 